\title{
MEASURING AND MONITORING OF AIR POLLUTION TO DEMONSTRATE COMPLIANCE WITH REQUIREMENTS
}

\author{
by
}

\section{N. Boegman}

\section{SYNOPSIS}

The application of the Atmospheric Pollution Prevention Act entails the monitoring of the effectiveness of the control actions. Different monitoring methods can result in very different costs not related to the efficiency of the monitoring. This problem is discussed.

\section{OPSOMMING}

Die toepassing van die Wet op Voorkoming van Atmosferiese Besoedeling behels die monitering van die doeltreffendheid van die beheer maatreëls. Verskillende moniterings metodes kan tot groot verskille in koste lei wat nie verband hou met die doeltreffendheid van monitering nie. Hierdie probleem word bespreek.

\section{INTRODUCTION}

Southern Africa developed very few industries during the period up to the present centruy, mainly because of its colonial history. The mining industry necessitated some basic manufacturing and service industries and a slow progress took place up to about 1940 , retarded significantly by the policy of exchanging gold and diamonds for manufactured goods rather than selling the produce and using the revenue to stimulate local capital investment and development.

The availability of a wide range of raw materials and labour, and the transportation crisis caused by World War II, sparked off a rapid growth period over the next four decades. This growth phase was so spectacular that South Africa can now be classified as an emerging industrial country over almost the whole spectrum of industrial activity. The periodic threats and actual boycotts helped in no small measure.

However desirable and necessary the industrialization may have been, it brought with it many problems, of which air pollution is by no means the least significant. Other factors like the inherently poor dispersion potential of the atmosphere over most of the country, contributes to compound the difficulties of maintaining satisfactory conditions.

\section{POLLUTION CONTROL COST}

The first, and at present by far the larger part of control cost lies in the acquisition and operation of abatement equipment. This cost rises very sharply with increased efficiencies of collection or removal of pollutants from a particular source.

The all important question is therefor, what level of reduction is necessary. Abatement cost is part of production cost, so the impact of unrealistic or unnecessary requirements may be crippling to the national economy because of its influence on the competative position of a country on the world market. This is particularly true for South Africa which is endowed with rich mineral resources and must depend heavily on primary industry and the export of semiprocessed products at this phase of its development.

The second cost element in pollution control is the monetary implications of the control function itself, spent by the authorities. This has been insignificant to date. Conservative estimates over the past decade places this expenditure at at less than $0,3 \%$ of the total, or considerably more costeffective than the collection of inland revenue.

The question now arises whether it would not be advantageous to increase the authority control function expenditure in order to try and reduce the possibility of over expenditure on abatement, caused by an over careful attitude in the absence of factual information.

\section{THE PROBLEM}

Air pollution has to be controlled to protect the human and his environment, and the highest quality of the atmosphere is desirable. Cost however precludes the ultimate in abatement efficiencies available through technology, purely on the cost-benefit principle. The solution therefore lies in maintaining an acceptable air purity. This requires that the air quality be monitored continually and everywhere.

The natural place to sample is the ambient environment, but then the concentrations are very low, and for meaningful representativeness, a large number of sampling points are essential.

The alternative is to sample all sources of pollution at their points of emission. In this case the number of points will be even larger, but the variety of pollutants at each source will be very much lower and the concentrations much higher and more easily measured. 


$$
\begin{aligned}
& \text { Droplets - Collection - Absorption on solid filters } \\
& \text { - Solution in suitable solvent } \\
& \text { - Quantification - Gravimetric } \\
& \text { - Wet chemical } \\
& \text { - Identification - Chromatography }
\end{aligned}
$$

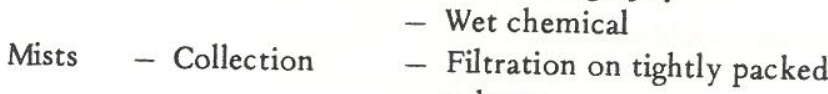

$$
\begin{aligned}
& \text { column } \\
& \text { - Quantification - Same as for droplets } \\
& \text { - Identification - Same as for droplets } \\
& \text { Organic } \\
& \text { gases - Collection - Adsorption on solids } \\
& \text { - Solution in solvents } \\
& \text { - Quantification+ - Gas chromatography } \\
& \text { Identification - Flame ionization } \\
& \text { - Electron capture } \\
& \text { - Element selective detectors }
\end{aligned}
$$

seldom create a problem at any distance from the source, can be collected on a large flat surface, and visual inspection will usually disclose their nature and source.

For all other pollutants various levels of sophistication of instrumentation is necessary for collection, identification and quantification.

\section{AMBIENT AIR MONITORING EQUIPMENT}

The most formidable problem is the low concentrations which must be catered for. Depending on the substance, it varies from parts of a microgram (fraction of a part per billion) to a few milligrams per cubic metre. If particulates are to be monitored, it entails sampling large volumes to obtain a workable sample size, while for gases the detection technique must be very sensitive.

To cover all possible detection and quantification techniques, requires an extensive study in its own right. The brief summary below will however give an indication of the variety of techniques which may be employed.

$$
\begin{aligned}
& \text { Dust - Collection - Centrifugal } \\
& \text { - Impaction } \\
& \text { - High volume medium pore } \\
& \text { filtration } \\
& \text { - Quantification - Gravimetric } \\
& \text { - Optical (stain) } \\
& \text { - Identification - Microscopic } \\
& \text { - Spectra } \\
& \text { - X-ray defraction } \\
& \text { - PIXIE } \\
& \text { - Neutron activation } \\
& \text { - Atomic absorption } \\
& \text { - Combustion } \\
& \text { - Wet chemical } \\
& \text { Fume - Collection - High volume fine pore } \\
& \text { filtration } \\
& \text { - Quantification - Gravimetric } \\
& \text { - Optical } \\
& \text { - Identification - Same as for dust }
\end{aligned}
$$

The problem is slightly more complex for inorganic gases in that a general method does not apply. A brief list of gases which can be monitored by different methods is given below.

$$
\begin{array}{ll}
\text { Wet chemical methods } & - \text { Most gases } \\
\text { Flame ionization } & -\mathrm{SO}_{2} \\
\text { UV spectrometric } & -\mathrm{SO}_{2}, \mathrm{NO}_{2}, \mathrm{O}_{3} \\
\text { IR spectrometric } & -\mathrm{CO} \\
\text { Electrochemical diffusion } & -\mathrm{CO}, \mathrm{H}_{2} \mathrm{~S}, \mathrm{SO}_{2}, \mathrm{NO}_{2}, \mathrm{Cl}_{2} \\
\text { Pulsed fluorescence } & -\mathrm{SO}_{2}, \mathrm{H}_{2} \mathrm{~S} \\
\text { Chemiluminescence } & -\mathrm{NO}, \mathrm{NO}_{2}, \mathrm{NO}_{\mathrm{x}}, \mathrm{NH}_{3}, \mathrm{O}_{3}
\end{array}
$$

\section{SOURCE MONITORING}

The concentrations to be measured are on average much higher than in ambient air, typically 100 to 10000 times, so that the concentrations range from milligrams to grams per cubic metre. On the other hand temperacorrosive.

In almost all cases the composition of the pollutants are known so that identification becomes unnecessary. Often it is possible to measure in-situ, obviating the collection step.

For solids and liquids throughout the size ranges, concentrations can be determined by light absorption, reflection or scatter, or by beta-ray capture. In some cases it is even possible to use semi-impaction or gravity settling as in the CEGB fly-ash monitor.

The techniques for identification and quantification of gases are very similar to those discussed for ambient air are so much higher. The equipment therefore can be made so much less sophisticated and therefore more robust and reliable, at a much lower price. tures are normally much higher and conditions are often monitoring. The only difference is that the concentrations 


\section{SCOPE FOR MONITORING REQUIRED}

Practically any combination of air pollutants have to be catered for in ambient air monitoring. In practice this is all but impossible. A very typical limited ambient air survey station would contain:

- A gravity type dust collector like cyclones or an impactor, for periodic quantification and identification of the samples.

- A fine pore filter to collect fume, also for periodic analysis.

- Equipment to sample droplets and mists for periodic assessment.

- A charcoal or other filter for adsorption or solution of organic vapours, for intermittent evaluation.

- Individual inorganic gas measuring trains to give continuous readings of:

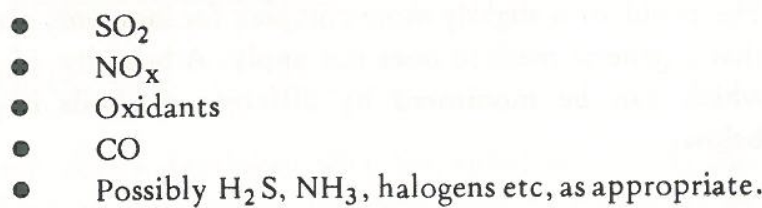

The station would also record wind direction and speed, temperature, possibly humidity and precipitation, and would be housed in an air conditioned space of not less than 15 square metre, with electrical supply, drains and telemetering facilities.

Depending on the degree of sophistication, a single unit station will cost between R100000 and R500000 in capital alone. In addition, a central laboratory will have to be provided for the handling of the discontinuous samples of solids, liquids and organic gases.

An isolated station would be of little value, so a grid will have to be established. A block pattern with 2 kilometer sides in all metropolitan areas would be ideal, but is beyond the realm of practice. A reasonable limit to spread is 5 kilometre. For the Reef area this would mean 100 to 200 stations, and for all the built up areas of the country it is likely to be twice that number. A national net would also require 5 central laboratories.

A budget for the crẹation of such a national ambient air quality monitor network could look something like the list below.

450 Stations at R120 000

5 Central laboratories at R1 000000

Telemetry and computer facilities
R54 million

R 5 million

$\mathrm{R} 3$ million

The annual running cost would be of the order of:

Equipment servicing

Equipment replacement to maintain system

Staff -450 at an all in cost of R20 000
Clearly such a monitoring network is at present well beyond the capabilities of South Africa, The initial cost would be more than $25 \%$ of the annual expenditure on abatement installations, and the operating cost would be about $25 \%$ of the operating cost of all existing abatement equipment.

If however it was found possible to finance and operate such a monitoring network, the results would only provide a record of the ambient air quality, but will not provide any eveidence of the source relationship if unsatisfactory conditions were recorded. Very often it may not even be possible to identify the offending source beyond doubt.

The alternative is to implement individual source monitoring. From the available records there are at present 1200 sites in South Africa where "scheduled processes" are being operated. Adding a further 800 significant non-scheduled source sites, the total to be considered comes to 2000 . For these, two pollutants per source and an average of three sources per site would appear to be realistic estimates.

The equipment cost is much lower, because of the higher concentrations to be measured, and as a rough guide, R3 000 to R10 000 per unit may be used for estimates. With this, the capital cost would be:

6000 sources with 2 pollutants each at R5 000 R60 million

The service cost, replacement and handling cost could be built into the management cost of the industries and although this would not reduce it significantly, administration would be easier.

With source monitoring the data will have to be transmitted to a central point for colation and interpretation. The central data collection point will have a very complex operation as data willcome in in dribs and drabs. This method will provide ideal information on any violations of prescribed emission limits, but will be of only indirect value in deciding if the ambient air quality is acceptable.

\section{WHICH APPROACH IS BEST}

In ambient air monitoring, even an incomplete coverage will cost more than the country can afford, but the information will relate directly to what we breathe.

Source monitoring will give a much wider coverage at the same cost and will provide evidence of transgresssions of legal requirements, but will only relate indirectly to ground level concentrations, as the calculation of dispersion to ground is very ccomplex and not always successful.

From the control authority's point of view, both sets of data are essential. Source monitoring will indicate if prescriptions are met, and ambient monitoring will confirm that the pre scriptions are in fact sufficiently strict to ensure public safety 


\section{CONCLUSIONS}

There is little doubt that the control authorities, both the Chief Air Pollution Control Officer and the local authorities, can make good use of monitoring data.

The first question is if South Africa can at this stage of development afford a comprehensive monitoring system, which should ideally include both sources and ambient air. The financial implication of a minimum meaningful network would be more than $\mathrm{R} 100 \mathrm{~m}$ initial capital and a running cost of the same magnitude per year.

The second question, if the financial difficulty can be overcome, is manpower. It is doubtful if an adequate source of suitably qualified and experienced technicians and scientists exist in this country. And even if such staff could be found, they could be far better employed in other fields like industrial instrumentation or telecommunications.

It is therefore submitted that notwithstanding the desirability of air pollution monitoring, other priorities of a higher order exist in South Africa at present for both money and manpower.
Over the past decade some elementary ambient monitoring of sulphur dioxide and smoke has been doen by local authorities with the aid of the CSIR, at very low cost. This should be maintained at all cost, and expanded both in extent and level of sophistication. The CSIR has also equiped some caravans with much more advanced instruments, capable of handling air pollution at ambient concentrations. This service should be maintained and extended, to do sampling as and when doubt exist in areas with higher than average pollution rates.

Stack monitoring has in the past few years become standard prescribed practice for cement plants, power stations, paper mills and some other individual industries. This tendency can be expanded as it becomes practical.

Since the initiation of air pollution control, sixteen years ago, the policy has been to move deliberately but carefully towards a modern but cost-effective system. At this delicate stage of development in both air pollution control and the industry of South Africa it would seem unwise to take too large a step into the future. Slower but steady progress will achieve the same end with much less disruption.

\section{NATIONAL ASSOCIATION FOR CLEAR AIR - AN AUDIO-VISUAL PROGRAMME ON AIR POLLUTION}

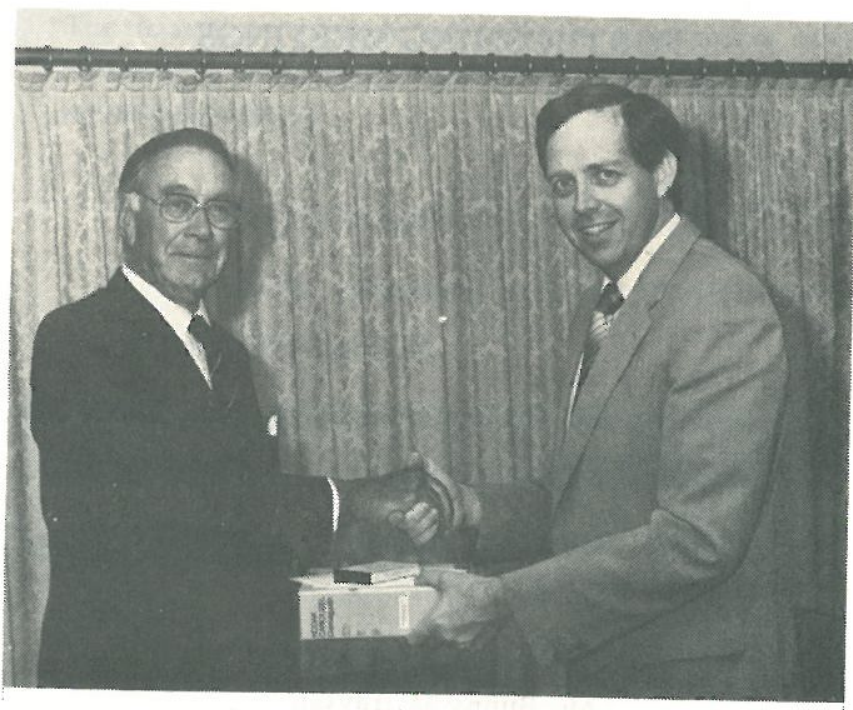

Dr. C.S. Keen (Chairman Western Cape Branch) producer of the Audio Visual Programme on Air Pollution handing over the official copy to the Director (J.L. Easterbrook).

The Long time dream of our Director Mr Jack Easterbrook has materialized in the form of an Educational Slide Series on AIR POLLUTION. An 80-slide carousel with a synchronized voice-tape commentary has recently been completed for the Association. The producer, Dr Cecil Keen of the University of Cape Town, on the 17 February 1982 formally handed over 4 copies of the Tape and Slide series to $\mathrm{Mr}$ Easterbrook for him to begin arranging their loan, hire or purchase on behalf of the Association.
The level at which the slide series has been produced is suitable for use in schools and at societies and institutions where interest is towards an understanding of "Air Quality' and in particular, Air Pollution. The emphasis is on education and an awareness of the implications of Air Pollution in our modern industrialized world. The commentary is somewhat provoking in that it makes the viewer take note of many of the issues involved in air Pollution, - its causes, its prevention and its control. Moreover, it also takes a sideways swipe at our apparent apathy towards striving for an improved quality to our environment. The overall coverage of the subject of Air Pollution is broad, posing and answering the obvious questions like what is ?', 'why?', 'should we be concerned?', 'why bother?', 'who is responsible ?', etc. It also presents a thorough coverage of the meteorological implications of Air Pollution and the effects pollution has on buildings, on plants and on (wo)man. The Slides are all in colour and are beautifully illustrated with word explanations titled or sub-titled on the slide to complement the voice commentary. The 80 -slide carousel will be supplied by the Association together with a pulsed voice-tape and a number of booklets which contain the transcript of the voice commentary. Thus it can be used either in an automatic type of projector system which will automatically advance the slides at the right time, or, the operator by listening for the audibel 'blip' on the tape and following the commentary in the transcript booklet, can manually advance the slides on cue. If the operator wishes, he may dispense with the voice tape and use the booklet as lecture notes and give his/her own commentary to the slides. 
The production of such a slide series obviously costs money; with drafting and art-work, film, slide moutns, slide duplication etc, the cost would have been beyond the running budget of NACA had it not been for the very generous donation and support received from Caltex Oil (S.A.). Their financial sponsorship together with their offer of the printing of the booklets containing the transcript of the voice commentary made the whole concept possible and the National Association for Clean Air is indebted and grateful to Caltex Oil (S.A.) for their support in this educational endevour.

It was felt necessary that each of the four branches of the Association have their own copy of the slide series to distribute in their local area. In this regard we are also indebted to Shell SA for their donation which covered the costs of duplication of the slide series, one copy for each of the branches.

Since many of the schools, particularly the less priveledged ones, do not have adequate facilities for viewing or projection of such a slide series, an automatic audio-visual system with built-in screen etc would be most useful aquisition for each branch. The projector-system could also be used as a foyer exhibit at symposia, conferences or meetings where the public would be subjected to an 'educational experience'! At a recent meeting of the NACA Council it was decided

\section{BRANCH NOTES}

\section{NATAL BRANCH}

$\begin{array}{ll}\text { Chairman: } & \text { K.R. Johnson } \\ \text { Secretary: } & \text { M.R. Skelly } \\ & \text { P.O. Box } 2443 \\ & \text { DURBAN } \\ & 4000\end{array}$

\section{EASTERN CAPE BRANCH}

$\begin{array}{ll}\text { Chairman: } & \text { J. Taylor } \\ \text { Secretary: } & \text { N.J. Vogt } \\ & \text { P.O. Box } 1124 \\ & \text { PORT ELIZABETH } \\ & 6000\end{array}$

\section{WESTERN CAPE BRANCH}

$\begin{array}{ll}\text { Chairman: } & \text { Dr. C.S. Keen } \\ \text { Secretary: } & \text { H.J. Linde } \\ & \text { P.O. Box } 384 \\ & \text { CLAREMONT } \\ & 7735\end{array}$

\section{TRANSVAAL BRANCH}

$\begin{array}{ll}\text { Chairman: } & \text { Dr. C.W. Louw } \\ \text { Secretary: } & \text { Dr. R.B. Wells } \\ & \text { P.O. Box } 395 \\ & \text { PRETORIA } \\ & 0001\end{array}$

that each of the branches would undertake to raise funds from functions, or by seeking donations to cover the costs of a projector system of their own.

The programme, at the moment is available only in English but towards the middle of the year the Afrikaans version will be available - our thanks and indebtedness again going to Caltex Oil (S.A.) for their promised support in this addition.

The audio-visual programme, with or without projector system, is available for:

(a) loan, to schools (where only a transportation cost

(b) hire, to institutions or society functions (at a very modest rate to cover insurance, depreciation and transport) or

(c) purchase.

Should you be interested in using this slide-tape programme on Air Pollution, please contact:

THE DIRECTOR (Mr Jack Easterbrook)

National Association for Clean Air

P.O. Box 5777

Johannesburg 2000

Phone: $011-41-0616$

\section{FORTHCOMING MEETINGS}

\section{ASOSH}

NOSHCON '82. Sun City, Wednesday, 26 May.

ASOSH One-day session -

The machinery and Occupational Safety Act, 1982, and Eyes in Industry.

Further information about ASOSH or NOSHCON '82 can be obtained by writing to:

The President of ASOSH

Mr. Bunny Matthysen

P.O. Box 26434

ARCADIA

0007

\section{NACA}

Symposium:

Venue:

400 Auditorium, CSIR Conference Centre, Pretoria

Date:

25 November 1982

Details :

To be advised. 


\section{PRESS RELEASE}

The National Association for Clean Air is an association whose members are very concerned that the inhabitants of South Africa should enjoy the benefits of a pollution free environment. The members consist of a borad spectrum of scientists and industrialists who work towards a common aim of ensuring the present conditions are either improved or maintained. The Association endeavours to educate the public by means of educational films, technical newsletters and an annual congress supported by eminent environmentalists.

The recent congress held at the CSIR had as its theme "Air Pollution - the Unseen Hazards". Mr. S.M. Lloyd, Chief Air Pollution Control Officer, in his summary of the congress, spoke of press critisicm of environmental conditions in South Africa which was based on generalised statements implying that South Africa had the worst air pollution in the world, the public were unknowingly inhaling highly toxic pollutants and that because there was no control by the authorities, there were no improvements in this state. These alarming statements were contradicted outright by such scientific papers entitled:

"Research in the CSIR on air pollution"

"Particulates in urban and industrial atmospheres of South Africa"

"The hazardous gaseous and volatile constituents which currently accompany particulates in the major S.A. urban/ ind ustrial centres"
"The control of gaseous pollutants"

"The state of knowledge regarding the epidemiological implications associated with air pollutants of the type and concentrations likely to be encountered in future in the Republic"

"Control and cost of air pollution"

"Measuring and monitoring to demonstrate compliance"

From these papers which were presented by members of the CSIR, the Department of Health and members of industry, it was shown that smoke levels over the last 10 years decreased by an average of about $50 \%$ and visibility in some places improved by a factor of 8 . Industry has conscientiously spent 1.7 billion rand on air cleaning equipment over the past decade with a current average annual spending of greater than 1 hundred million rand and this enormous sum of money was spent on effective air cleaning equipment only and not on counter productive litigation as the case elsewhere in the world. Information regarding emissions from the various industries is available for anyone who is involved or affected. Surveys carried out by both the CSIR and the Atomic Energy Board show that 15 of the most important organic substances in the atmosphere and 25 of the most important trace elements were comparable with those encountered in other cities across the world. Apart from these country wide surveys regular monitoring of specific pollutants is carried out at all major factories. Where levels of hydrocarbons have varied the necessary action is being taken by the authorities. To summarise then South Africa has a relatively pollution free atmosphere which it is making every attempt to retain.

\section{THE FOLLOWING ANNOUNCEMENT APPEARED IN THE IUAPPA NEWSLETTER}

VOLUME 6 - NUMBER 34

\section{VIth IUAPPA WORLD CONGRESS ON AIR QUALITY}

PARIS May 16th - 20th 1983

The VIth World Air Quality Congress to be held by the International Union of Air Pollution prevention Associations (IUAPPA) will take place at the Palais des Congres, Paris, from May 16 th to 20 th 1983.

The Association for the Prevention of Atmospheric Pollution (APPA), France, a founder member of IUAPPA, is responsible for the organisation of the Congress.

President :

Doctor Michel Sommer, President of the IUAPPA

Vice-President: Mr. Pierre Bapseres, Vice-President of the IUAPPA

Secretary General: Mr. Jean-Rene Delandre, Director of the APPA.

\section{List of subjects accepted for discussion}

1. The physics, chemistry and measurement of pollutants

2. Atmospheric pollution and health

3. Olfactive nuisances

4. Atmospheric pollution and plants

5. Atmospheric pollution and materials

6. The meteorology and physics of the atmosphere

7. Preventive techniques - the reliability and safety of installations - Economic evaluation

8. Radioactivity in the air

9. Automotive Pollution

10. Pollution caused by replacement energies

\section{Papers}

A CALL FOR PAPERS will be issued in September 1981, with details of the subjects to be covered.

Abstracts should be addressed to the National Programme Committee NACA P.O. Box 5777, Johannesburg, 2000, who will make an initial selection before presenting them to the International Programme Committee. 